\title{
Development and survivability of ovarian follicles of goat in different feeding systems
}

\author{
MH Alam, ME Kabir, MB Sarker, BK Saha, RI Khan, M Moniruzzaman*
}

Department of Animal Science, Bangladesh Agricultural University, Mymensingh 2202; ${ }^{1}$ Department of General Animal Science and Animal Nutrition, Patuakhali Science and Technology University, Babugonj, Barisal 8210, Bangladesh

\begin{abstract}
The present study was aimed to know the effects of feeding systems on follicular development in Black Bengal goats. Nine female post-weaned Black Bengal goats were randomly assigned to 3 feeding systems namely stall feeding, tethering and grazing. After 240 days of rearing, goats were slaughtered and ovaries were collected for morphometric analysis. Histological examination revealed that the percentages of secondary $(p<0.01)$ and antral follicles $(p<0.05)$ were higher in stall-fed than tethering and grazing goats. Percentage of primordial follicles $(61 \pm 2 \%)$ was lower in stall-fed goats and higher in tethering $(71 \pm 3 \%)$ goats. Number of degenerated follicles was higher in tethering goats and lower in stall-fed groups. These results reveal that development and degeneration of ovarian follicles are influenced by feeding systems of goats.
\end{abstract}

Key words: Follicles, goat, grazing, ovary, stall feeding, tethering

Bangladesh Animal Husbandry Association. All rights reserved. Bang. J. Anim. Sci. 2014.43 (3): 175-179

\section{Introduction}

Black Bengal is a promising dwarf meat type breed of goat which is distributed in Bangladesh and India. They are regarded as intimate and integral part of subsistence traditional rural farming system. These indigenous goats have an excellent ability to accommodate and adapt to fluctuation in environment. The ability to accommodate to fluctuation in environment often involves some degree of reproductive failure (Devendra and Burns 1983). Infertility of does in many cases is manifested by abnormalities in the reproductive organs (tract and gonads). Ovary is vital organ that supplies the female germ cells, i.e., oocytes, and produces hormones for maintaining reproductive health.

In ovaries, oocytes are enclosed by a single layer of squamous granulosa cells to form primordial follicles. Oocytes in primordial follicles grow accompanied by follicular development through primary, secondary and antral stages and are finally ovulated. Recently, lower number of ovarian follicles is considered as one of the major

*Corresponding Author: monir.as@bau.edu.bd causes of infertility in Black Bengal goats (Amin et al. 2005). Factors that regulate the follicular development in goat ovaries are not clearly known. However, several factors are known to be responsible for the follicular development in mammals (Skinner 2005). The effect of environment, dietary and management related factors on initial follicle endowment and their subsequent growth is not understood well. Animals are exposed to adverse climatic conditions, e.g., acute sun shine, high temperature, humidity, rainfall and cool weather in tropical countries like Bangladesh. The effect of environmental factors on development of follicles has not been understood. In Bangladesh, goats are reared in several feeding systems such as free grazing, tethering and stall feeding. Our previous study revealed that growth rates of Black Bengal goats vary depending on feeding systems (Moniruzzaman et al. 2002). Few attentions have been paid to know the reproductive performance of goats in different feeding systems in that study. However, effects of feeding systems on ovarian follicular development and survivability are not known yet. 


\section{Goat ovarian follicles in different feeding systems}

\section{Materials and methods}

The experiment was conducted with nine female Black Bengal goats of around 8 months. Their initial body weight ranged from 6.5 to $8 \mathrm{~kg}$. Before starting the experiment, they were allowed to adjust themselves for four weeks with the experimental conditions and diets. Goats were housed in 3 separate pens and 3 goats were kept in each. Each pen was 44 square feet and the house was well ventilated. The gunny bag was hung over the ventilator to protect rain and wind. The floor, feeder and water trough were cleaned everyday using phenyl as antiseptic where necessary. Separate feeder was used for roughage and concentrate feeding. The goats were identified with ear tags. Anthelmentic drug (Dovenix, Advance Pharmaceuticals Company Limited, Hong Kong, China) was administered according to the instruction of the manufacturer to deworm the goats. Goats were vaccinated against the PPR (Peste des Petits Ruminants) supplied by Department of Livestock Services, Bangladesh following the instructions of the manufacturer.

Three feeding systems namely stall feeding, tethering and grazing were practiced for three different groups of does. For stall feeding group, ration was formulated using commonly available feed ingredients including natural grass, wheat bran, maize, soybean meal, molasses, DCP (dicalcium phosphate) and common salt to supply $10.40 \mathrm{MJ} / \mathrm{kg}$ DM metabolizable energy (ME), 14\% crude protein (CP) according to the NRC (1981) feeding standard. Nutrient composition and amount of diets were adjusted on the basis of live weight change of the animals at every fifteen days interval. The concentrate mixture was supplied first and then green grass was fed. The ration was supplied in two equal parts in the morning and evening. For grazing group, goats were allowed to graze in the field from 8 am to 5 pm. Natural grasses including Carpet grass (Axonopus compresus), Ulu grass (Imperata cylindrica), Durba grass (Cynopodon dactylon) and Mutha grass (Cyperus rotundus) were usually found in the grazing field. In tethering group, goats were tethered from 8 am to $5 \mathrm{pm}$ at the place of grazing and were moved at one hour interval. A peg and a rope of 20 feet in length were used for tethering. Fresh drinking water was supplied to all groups ad-libitum basis.

After 8 months of rearing, all the does were sacrificed for collection of ovaries. After collection, ovaries were transported to the laboratory within 1 hour. Adipose tissues surrounding the ovaries were removed carefully. Ovaries were fixed in Bouin's solution for $8 \mathrm{~h}$. After washing in Dulbecco's phosphate buffered saline (PBS), ovarian tissues were dehydrated in alcohol, cleared in xylene and embedded in paraffin. Serial sections of $5 \mu \mathrm{m}$ were prepared by a rotatory microtome. Sections were deparaffinized in xylene and rehydrated in alcohol. Then, the sections were stained with haematoxylin and eosin. Finally, the stained sections were permanently mounted with cover slip using DPX mounting reagent.

From the serial sections, every fifth sections were observed under a light microscope. The numbers of $\mathrm{CL}$ (corpora lutea) and different stages of follicles were recorded. The follicles were counted in the section where the oocyte nucleus was seen. Double counting was avoided. The follicles were classified into four categories according to the number and morphology of granulosa cell layers as: i) Primordial follicle with a single layer of flattened granulosa cells surrounding the oocyte, ii) Primary follicle with a single layer of cuboidal granulosa cells, iii) Secondary follicle with two or more layers of granulosa cells but no antrum, iv) Antral follicle having an antral cavity with multiple layers of granulosa cells. Follicles were considered degenerated if they contained oocytes with pyknosis, large vacuoles, condensed cytoplasm, disappearing of nuclear membranes, shrinkage of nucleus, swollen granulosa cells or loss of granulosa cells.

All data were analysed using "MSTAT" statistical programme to compute analysis of variance for CRD. The means were compared with Duncan's multiple range test. 


\section{RESULTS}

Histological examination revealed (Figure 1) that percentage of non-growing primordial follicles was higher $(p<0.05)$ in goats managed under tethering system $(71 \pm 3 \%)$ than others while those did not differ between stall-fed $(61 \pm 2 \%)$ and grazing $(62 \pm 4 \%)$ groups (Table 1$)$. Percentage of primary follicles $(25 \pm 2 \%)$ was higher in grazing goats than stall-fed $(20 \pm 1 \%)$ and tethering feeding $(22 \pm 2 \%)$ groups. Percentage of secondary follicles was significantly higher $(p<0.01)$ in stall-fed $(11 \pm 1 \%)$ than tethering $(4 \pm 1 \%)$ and grazing $(7 \pm 1 \%)$ feeding systems. Similarly higher percentage of antral follicles was found in stall-fed $(9 \pm 2 \%)$ than tethering $(3 \pm 1 \%)$ and grazing $(6 \pm 1 \%)$ feeding goats (Figure 2 ).

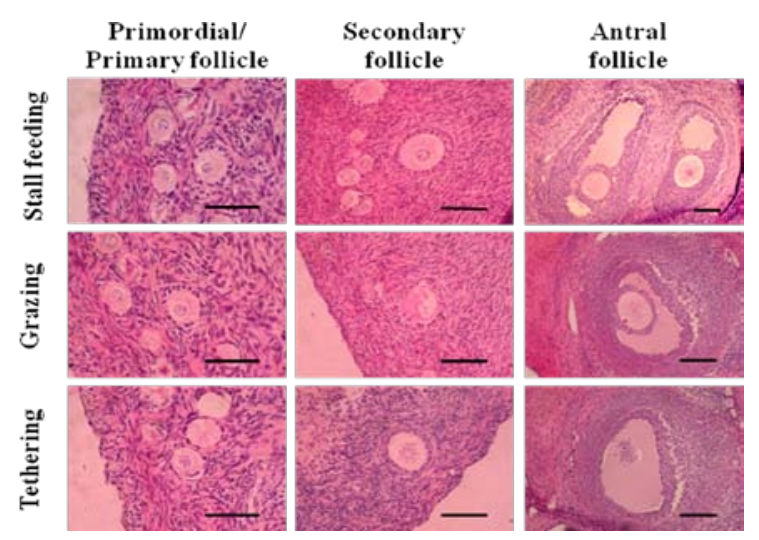

Figure 1. Histological sections of ovaries of stall-fed, grazing and tethering goats. Scale bars represent $100 \mu \mathrm{m}$.

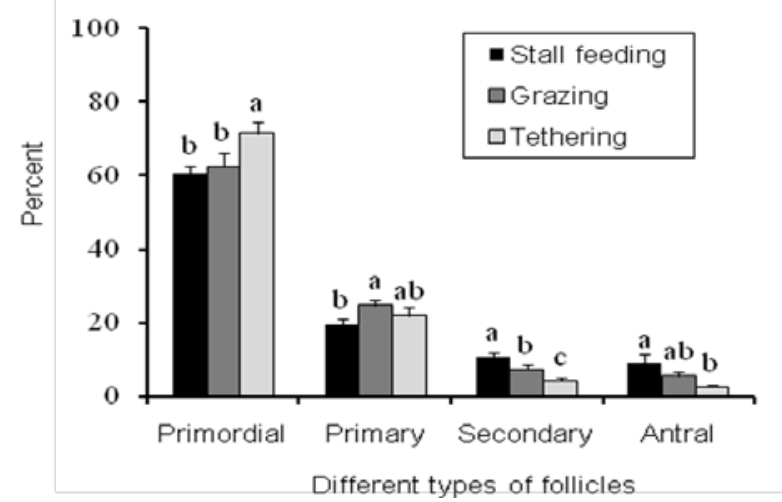

Figure 2. Different types of ovarian follicles (\%) in stall-fed, tethering and grazing goats; within the same category differed significantly $(p<0.05)$
Table 1. Effect of feeding systems on number of different types of follicles in ovaries

\begin{tabular}{lccc}
\hline Types of & \multicolumn{3}{c}{ Number of follicles per ovary } \\
\cline { 2 - 4 } follicles & Stall feeding & Grazing & Tethering \\
\hline Primordial & $307^{\mathrm{b}} \pm 19$ & $33^{\mathrm{b}} \pm 20$ & $38^{\mathrm{a}} \pm 26$ \\
Primary & $100^{\mathrm{b}} \pm 14$ & $131^{\mathrm{a}} \pm 9$ & $119^{\mathrm{a}} \pm 10$ \\
Secondary & $55^{\mathrm{a}} \pm 10$ & $39^{\mathrm{b}} \pm 8$ & $22^{\mathrm{c}} \pm 4$ \\
Antral & $46^{\mathrm{a}} \pm 13$ & $29^{\mathrm{a}} \pm 8$ & $14^{\mathrm{b}} \pm 2$ \\
\hline
\end{tabular}

Means with uncommon superscripts at the same row differed significantly $($ Mean $\pm S D)$

The numbers of degenerated primary, secondary and antral follicles were significantly $(p<0.05)$ higher in goats managed in tethering than grazing and stall-fed goats (Table 2). Different types of degenerated follicles found in the goats managed tethering system are shown in Figure 3. Number of primordial degenerated follicles did not differ $(p<0.05)$ among the goats of three feeding systems.
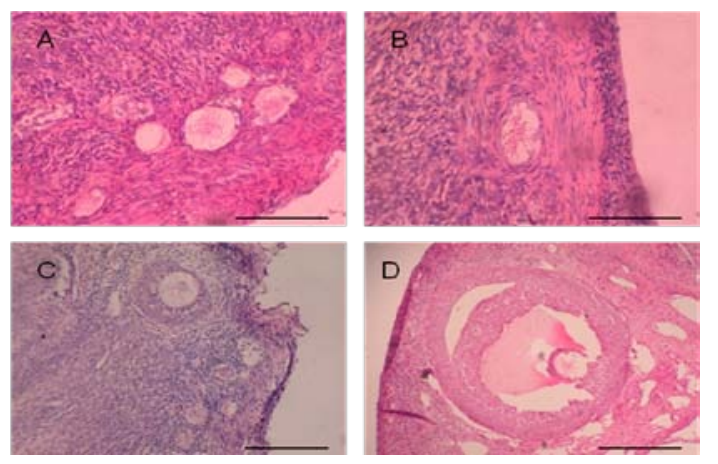

Figure 3. Different types of degenerated follicles in tethering feeding group ( $A$, primordial follicle; $B$, primary follicle; $C$, secondary follicle; $D$, antral follicle). Scale bars represent $100 \mu \mathrm{m}$.

Table 2. Effect of feeding systems on number of different types of degenerated follicles in ovaries

\begin{tabular}{lccc}
\hline Types of & \multicolumn{3}{c}{ Number of follicles per ovary } \\
\cline { 2 - 4 } follicles & Stall feeding & Grazing & Tethering \\
\hline Primordial & $27 \pm 7$ & $44 \pm 17$ & $59 \pm 11$ \\
Primary & $13^{\mathrm{b}} \pm 4$ & $21^{\mathrm{ab} \pm 4}$ & $31^{\mathrm{a} \pm 6}$ \\
Secondary & $9^{\mathrm{b}} \pm 3$ & $11^{\mathrm{b}} \pm 5$ & $21^{\mathrm{a}} \pm 5$ \\
Antral & $7^{\mathrm{b}} \pm 1$ & $11^{\mathrm{ab} \pm 3}$ & $16^{\mathrm{a}} \pm 4$ \\
\hline
\end{tabular}

Means with uncommon superscripts at the same row differed significantly $($ mean $\pm S D)$ 


\section{Goat ovarian follicles in different feeding systems}

\section{Discussion}

In mammals, reproductive performance largely depends on the reserve of healthy oocytes, dynamics of follicular development and endocrine function of the ovary. Follicular development together with oocyte enlargement is essential for the fertility of an animal. Factors regulating the development of ovarian follicle are not known well. In the present experiment, increased proportion of developed follicles was found in stall-fed than grazing and tethering goats. A similar result was reported by Siddique et al. (2010) who compared the development of ovarian follicles in Black Bengal does under intensive and extensive production system. Lower rate of folliculogenesis and higher degeneration of follicles were found in extensive production system in comparison with intensive production system. Proportion of developed follicles was lower in summer compared with winter season (Bari et al. 2011). Moniruzzaman et al. (2002) previously reported higher reproductive performance in stall-fed than tethering and grazing goats. The present study showing higher rate of follicular development in stall-fed goats supports our previous reports of higher prolificacy in the same feeding system comparing tethering and grazing goats. The higher rate of folliculogenesis in stall-fed goats may be due to the better body condition, minimum energy loss for grazing and few exposure of environmental stress comparing tethering and grazing groups. On the other hand, goats reared in tethering and grazing systems suffered from different types of parasitic infestations (Moniruzzaman et al. 2002). Due to loss of energy for roaming, less amount of nutrients remained for reproductive purpose. This might cause the poor developmental rate of ovarian follicles in grazing and tethering goats.

Significantly $\quad(p<0.05)$ higher number of degenerated follicles was observed in ovaries of tethering goats. This might be due to environmental stress specially heat stress. Heat stress might be one of the important factors that affected the follicular development of goat managed in outside environment (grazing and tethering). We previously reported that lower rate of development and higher rate of degeneration of ovarian follicles occurred in goat ovaries during summer than winter season (Bari et al. 2011). Wolfenson et al. (1995) also reported that heat stress impaired follicular development and altered the dominance of the first-wave dominant follicle and the preovulatory follicle in lactating dairy cattle. Siddique et al. (2010) found lower rate of follicular development and higher rate of follicle degeneration of goats in extensive than intensive system. It is well known that factors such as high temperature and humidity are associated with marked declines in the reproductive efficiency of cattle (Fernandez et al. 1962; Cran et al. 1987; Du et al. 1991; Thatcher and Collier 1986). This result supports the heat stress induced degeneration of ovarian follicles in tethering and grazing goats in the present experiment. Higher number of parasites usually found in tethering and grazing goat groups than stall-fed group (Moniruzzaman et al. 2002). Higher parasitic infestation of tethering and grazing goat groups might cause the poor body condition of goats which may ultimately cause the retardation of follicular development in tethering and grazing goats comparing stall-fed group.

\section{Conclusion}

The present study showed that the rate of follicular development was lower in tethering than stall-fed and grazing goats. Moreover, the number of degenerated follicles was significantly higher in tethering than stall-fed and grazing goats. So, the follicular development and survivability were higher in stall-fed and lower in tethering group. These results suggest that higher prolificacy in stall-fed goats is associated with higher rate of follicular development.

\section{References}

Amin MR, Salim MS, Khandoker MAMY, Hossain MM (2005). Causes of infertility in Black Bengal does investigated by anatomical and histological tools. Progressive Agriculture, 6: 117-124.

Bari MA, Kabir ME, Sarker MB, Khan AHNA, Moniruzzaman M (2011). Morphomatric 
analysis of ovarian follicles of Black Bengal goat during winter and summer season. Bangladesh Journal of Animal Science, 39: 51-55.

Cran DG, Osborn JC, Rushton D (1983). Thecal vasculature and oocyte maturation during follicular atresia in the sheep and pig. Reproduction, Nutrition, Development, 23: 285-292.

Devendra C, Burns M (1983). Goat production in the tropics. Second edition. Commonwealth Agricultural Bureau, Farnham House, Farham Royal, U. K.

Du M, Thatcher WW, Putney JO (1991). Effects of heat stress on fertility in dairy cattle. In Proceedings of Annual Meeting, Society for Theriogenology, pp. 49-53.

Fernandez LL, Mandl A, Zuekerman S (1962). The development of the ovary and the process of oogenesis. In: S. Zuekerman(Ed), The ovary, Academic Press, London, 1, 1-88.

Moniruzzaman M, Hashem MA, Akter S, Hossain MM (2002). Effect of feeding systems on feed intake, eating behavior, growth, reproductive performance and parasitic infestation of Black Bengal goat. AsianAustralasian J ournal of Animal Science, 15: 1453- 1457.
NRC (1981). Nutrient requirement of domestic animals. Nutrient requirements of goats, agora, dairy and meat goats in temperate and tropical Countries. Vol 15, National Academy Press, Washington, D.C.

Siddique MA, Amin MR, Islam R, Goswami C, Ullah MSF (2010). A comparative study on the follicular development of Black Bengal Goat under intensive and extensive production system. International Journal of BioResearch, 1: 19-23.

Skinner MK (2005). Regulation of primordial follicle assembly and development. Human Reproduction Update, 11: 461-471.

Thatcher WW, Collier D (1986). Early follicular development and atretic changes on ovary of the lamb-fine structure and histochemistry. Australian Journal of Biological Science, 33: 675-687.

Wolfenson D, Thatcher WW, Badinga L, Savio JD, Meidan R, Lew BJ, Braw-Tal R, Berman A (1995). Effect of heat stress on follicular development during the estrous cycle in lactating dairy cattle. Biology of Reproduction, 52: 1106-1113. 